\title{
Dynamic Relationship Between Capital Structure and Quoted Manufacturing Firms' Performance in Nigeria
}

\section{Oyedeji Rasheed Olarewaju}

Department of Management and Accounting, Faculty of Management Sciences, Ladoke Akintola University of Technology, Ogbomoso, Oyo State, Nigeria

Email address:

michaelly04@yahoo.com

\section{To cite this article:}

Oyedeji Rasheed Olarewaju. Dynamic Relationship Between Capital Structure and Quoted Manufacturing Firms' Performance in Nigeria. International Journal of Economics, Finance and Management Sciences. Vol. 7, No. 3, 2019, pp. 82-87. doi: 10.11648/j.ijefm.20190703.11

Received: May 15, 2019; Accepted: June 18, 2019; Published: July 1, 2019

\begin{abstract}
For so long, and most recently, relationship between capital structure and manufacturing firm's performance has been an issue in financial world. Financial analysts are controversial in advising the investors on the best capital structure to employ while undertaking investment decisions. This paper investigates dynamic relationship between capital structure and quoted manufacturing firms' performance in Nigeria from 1990-2016. Using panel unit root test to verify the stationarity property of the data, Pedroni conitegration tests and Panel Vector Error Correction Method (PVECM) are employed to examine the equilibrium among the variables as well as analysing the data. There is evidence of long run relationship between capital structure and firms' performance in Nigeria as revealed by Cointegration test results. Results from PVECM show that, throughout the period i.e. both in the long run and short run, except itself, none of the variables' shocks in the system significantly accounts for variations in the returns on asset (ROA), given variance error decomposition's statistics. Also, both in the short run and long run, innovations from only equity (EQU) explains, on average, 1.76\% variations to profit margin. Arising from these findings, the study could not find dynamic relationship between capital structure and firms' performance. The study, therefore, recommends that manufacturing firms should be pragmatic when choosing capital structure outlays to enhance performance in their activities.
\end{abstract}

Keywords: Dynamic, Capital, Manufacturing Firm, Performance

\section{Introduction}

Appropriate capital structure decision is one of the most crucial decisions often confronted with by financial analysts and managers of firms, especially in developing economies. The decision center's on the mix of debts and equity in financing firm's immediate and long term assets and operations. In as much as profits maximization remains a primary objective of business firms, capital structure decision is sacrosanct to business firms as well. It facilitates maximization of returns on investment over a long-run perspective while risks are curtailed through the efficiency of project financing, mergers, acquisition and expansion as well as dividend-sharing decisions [1].

A company's capital structure generally shows all the sources of finance a company is utilising to finance its operations. It is used as a benchmark when raising funds for investment project (s) in new capital projects [2]. Therefore, questions burdening on the choice of debt or equity, optimal capital structure of a firm and potential determinants of such optimal capital structure, require crucial decisions [3]. It is obvious, since firm's size does not remain stagnant for long and so does the cost of capital due to constant changes in interest rates and inflation, the risks inherent in capital mix also perpetually remains dynamic. Thus, optimal capital structure to facilitate appreciable performance should continue to change. Therefore, what is so important is identifying the capital structure that derives firm's sustainable performance over time to enable the financial manager continuously keep informed on how and when to adjust.

In empirical management literature, it is argued that firm performance reflects how effectively company manages its resources while there is a multitude of capital structure indicators which influence its operations. The study of capital structure in relation to firm's performance is, therefore, of 
great interest in the study of Corporate Finance and Accounting. Hence, the study is significant in enhancing managerial decisions. Its importance is also derived from the fact that capital structure is tightly related to the performance of firms while fulfilling the interests of various stakeholders of companies [4].

In financial management, particularly in Nigeria, empirical studies have focused on capital structure and its determinants, even though a consensus has not been reached. Also, studies have concentrated on the best combination of debt-equity in financing quoted manufacturing firms' operations. However, evidence on dynamic relationship between capital structure and firms' performances remains elusive in empirical literature in Nigeria. Therefore, this study examines the dynamic relationship between capital structures and quoted manufacturing firms performance in Nigeria from 1990 to 2016. Examining the dynamic relationship between firm's capital structure and its performance becomes necessary as individuals and corporate organisations make investment decisions based on the records of performance of the prospective businesses.

\section{Literature Review}

Several authors have investigated the determinants of capital structure of quoted and unquoted firms for different economies, using different methods. Tian and Zeitun (2007) investigated the effect of capital structure on corporate performance of corporations in Jordan using a panel data comprising 67 companies during the period 1989-2003. The study estimated different measures of corporate performance such as the returns on assets (ROA), returns on equity (ROE), earnings before interest and tax plus depreciation to total assets (PROF). Employing both the accounting and market measurements, the results showed that a firm's capital structure has a significant negative impact on the firm' performance and that the short term debts to total assets has a significantly positive effect on the performance [5].

De Angelo and Masuli (1980) analysed the importance of firm-specific and country-specific factors in the capital structure choice of firms from 42 countries. The study employed secondary data sourced from World Bank database for the period 1997-2007. Ordinary least square (OLS) regression method was used. The study revealed that the firm-specific determinants of leverage differed across countries and further showed an indirect impact of countryspecific factors on the capital structure of firms. The overall empirical results indicated that the conventional theories on capital structure developed using listed firms in the United State as a model worked well in similar countries with developed legal environment and high level of economic development [6].

Getzmann and Spremann (2010) studied determinants of the target capital structure and adjustment speed-evidence from Asian capital markets. The study used a management panel of 1030 companies with market capitalization at least 1 billion USD, listed on 14 Asian stock exchange. Using generalised methods of moment technique, the study found strong evidence that Asian companies pursued target capital structure during the period under review. The authors concluded that industry-fixed assets influenced capital structure choice in Asia [7]. In another case, Mishra (2011) investigated determinants of capital structure in manufacturing sector of India Central Public Sector Undertakings. The study drew a sample of 48 profit making manufacturing PSUs, for the period of 2006 to 2010. The study employed multiple aggression analysis to determine the factors affecting capital structure. The results showed that the capital structure of the profit making PSUs is affected by asset structure, profitability and tax. The results indicated that firms with less effective tax rate would go for more debts and vice versa [8].

Ajeigbe, Fasesin and Ajeigbe (2013) studied Nigeria ailing industries and the capital structure theory. The authors used multiple regression analysis to examine the ailing manufacturing companies in Nigeria for the period of 20052015. The study measured capital structure determinants by using the variables of capital intensity, tangibility, profitability, firm size and non-debt tax shield. The results were consistent with the explanation of trade-off theory that capital structure of manufacturing companies must be given premium consideration [9]. Chechet Garba and Odudu (2013) examined the determinants of capital structure in quoted chemical and paint companies in Nigeria from2005 to 2009. Using secondary data, the study employed Ordinary Least Square (OLS) to determine whether relationship existed between leverage ratio and various independent variables in the models. The study revealed that for the Nigeria Chemical and Paint Sector, tangibility and profitability have significant impact on leverage [10]. Also, Hasan, Ahsan, Rahaman, and Alam (2014) investigated the influence of capital structure on firm's performance in Bangladesh during the period 20072012. Using pooling panel data regression method, the study found that firm's performance was positively related to shortterm debt while it was negatively related to long-term debt [11].

Javed, Younas and Imiran (2014) explored the impact of capital structure on firm performance of 63 companies listed on Karachi Stock Exchange from 2007 to 2011. The study employed Fixed Effects Model and the results showed that there existed a relationship between firm performance and capital structure, although the direction was not clear [12]. Similarly, Hossain and Nguyen (2016) examined the effect of financial leverage on firm performance in Canadian oil and gas companies from 2004 to 2013. The study found that leverage has a strong negative correlation with performance throughout the period reviewed [13]. Nenu, Vintila and Gherghina (2018) analysed the evolution of the main theories regarding the capital structure and the related impact on risk and corporate performance. The study equally investigated the drivers of capital structure of the firms from the Romanian market from 2000 to 2016 . Using dynamic paneldata technique of two-step system generalized method of moments on companies listed on the Bucharest Stock 
Exchange; the results showed that leverage was positively related to the size of the company and the share price volatility, while debt structure has a different impact on corporate performance [14].

\section{Data and Methodology}

Secondary data used in this study are obtained from Nigeria Stock Exchange Fact book, 2016 and it includes returns on asset (ROA) measured as net income divided by asset, profit margin (PRM) measured as earnings before tax divided by total asset, short term loan (STD) measured as loans below one year of maturity, long term debts (LTD) as loans above one year of maturity and equity (EQU) as owners' funds. The sample size of this study comprises 30 quoted manufacturing companies in Nigeria and the period covers 1990-2016. Considering the interest of the shareholders which is the concern of the business world, there are two major measures of firm's performance, namely; Returns on Assets (ROA) and Profit Margin (PRM). However, when investigating capital structure and firms' performance, these two measures are not commonly distinguished in empirical studies in Nigeria. Following [15], to examine the relationship between capital structure and firms' performance in Nigeria, the models start as follows:

$$
P E R F=f(S T D, L T D, T D B, E Q U)
$$

Where PERF represents firms' performance, STD stands for short-term debts, LTD is long-term debts, TDB denotes total debts and EQU is equity. It should be noted that this study uses panel econometric analysis due to the number of manufacturing firms captured by the analysis. Therefore, the model is rewritten to reflect the panel modelling:

$$
P E R F_{i t}=\left(S T D_{i t}, L T D_{i t}, T D B_{i t}, E Q U_{i t}\right)
$$

Subscript $i$. denotes the number of manufacturing companies captured and $t$ represents time. Rewriting equation (2) in econometric models to encompass the two measures of performance, hence the following models are specified with each representing different measures of firm's performance;

$$
\begin{gathered}
R O A_{i t}=\begin{array}{c}
\alpha_{0}+\beta_{1} S T D_{i t}+\beta_{2} L T D_{i t}+\beta_{3} T D B_{i t}+ \\
\beta_{4} E Q U_{i t}+\varepsilon_{t}
\end{array} \\
P R M_{i t}=\begin{array}{c}
\gamma_{0}+\gamma_{1} S T D_{i t}+\gamma_{2} L T D_{i t}+\gamma_{3} T D B_{i t}+ \\
\gamma_{4} E Q U_{i t}+\varepsilon_{t}
\end{array}
\end{gathered}
$$

To conform with the objective of the study i.e. examining the dynamic relationship between capital structure and firms' performance in Nigeria, firms' performance is decomposed into returns on asset (ROA) and profit margin (PRM). This constitutes a marked departure from the existing literature in Nigeria, hence the choice of Vector Error Correction Mechanism (VECM) to analyse equations (3) and (4). Again, given the panel nature of the study, thus, dynamic panel vector error correction models (DPVECM) are specified.

\section{Model Specification}

To examine the relationship between capital structure and manufacturing firms' performance, equations (3) and (4) are modified and specified in VEC model. The VAR model is stated thus:

$$
\mathrm{U}(\mathrm{VAR})=(\mathrm{ROA}, \mathrm{PRM}, \mathrm{STD} \text { LTD, EQU) }
$$

Where ROA represents returns on asset, PRM stands for profit margin, EQU equals equity, STD represents short term debts and LTD connotes long term debts of selected quoted manufacturing firms in Nigeria. More explicitly, equation (5) can be expressed as,

$$
X_{t}=\delta+\gamma_{1} X_{t-1}+\gamma_{2} X_{t-2}+\gamma_{3} X_{t-3}+\ldots+\gamma_{q} X_{t-p}+\varepsilon_{t}
$$

$X_{t}$ is a $2 \mathrm{X} 1$ dimensional Vector of the endogenous variables, $\delta$ is a $\mathrm{k} X 1$ dimensional Vector of constants, $\gamma_{1} \ldots . \gamma_{q}$ is $\mathrm{k} \mathrm{X} \mathrm{k} \mathrm{dimensional} \mathrm{autoregressive} \mathrm{coefficient}$ matrixes and $\varepsilon_{t}$ represents $\mathrm{k}$ dimensional stochastic error terms that follows iid i.e. identically independently distribution. Expressing equation (6) in VEC model provided that the variables are cointegrated:

$$
\Delta Y_{t}=\delta+\Gamma_{1} \Delta Y_{t-1}+\ldots \Gamma_{p-1} \Delta Y_{t-p+1}+\Pi Y_{t-1}+\varepsilon_{t}
$$

$\Delta$ is the first difference operator and $\Pi$ is of rank $1 \leq \mathrm{r}<2$. Decomposing $\Pi$ into $\Pi=\alpha \beta^{\prime}$ where $\alpha_{2 \times 1}$ and $\beta_{2 X 1}$ then, equation that follows can be expressed as:

$$
\Delta Y_{t}=\delta+\Gamma_{1} Y_{t-1}+\ldots \Gamma_{p-1} \Delta Y_{t-p+1}+\alpha\left(\beta^{\prime} Y_{t-1}\right)+\varepsilon_{t}
$$

The rows of $\beta$ are interpreted to mean distinct cointegration vectors and $\alpha$ s are the adjustment coefficients, indicating the adjustments to long-run equilibrium. Formulating equation (8) in VEC Model, we obtain the following equations:

$$
\begin{gathered}
\Delta R O A=\beta_{O}+\beta_{i} \sum_{j=0}^{n} \Delta S T D_{(t-j)}+\beta_{i} \sum_{j=0}^{n} \Delta L T D_{(t-j)}+\beta_{i} \sum_{j=0}^{n} \Delta P R M_{(t-j)}+\beta_{i} \sum_{j=0}^{n} \Delta E Q U_{(t-j)}+\pi E C M_{(-1)} \\
\Delta P R M=\psi_{O}+\psi_{i} \sum_{j=0}^{n} \Delta S T D_{(t-j)}+\psi_{i} \sum_{j=0}^{n} \Delta L T D_{(t-j)}+\psi_{i} \sum_{j=0}^{n} \Delta R O A_{(t-j)}+\psi_{i} \sum_{j=0}^{n} \Delta E Q U_{(t-j)}+\phi E C M_{(-1)} \\
\Delta S T D=\zeta_{O}+\zeta_{j} \sum_{j=0}^{n} \Delta R O A_{(t-j)}+\zeta_{j} \sum_{j=0}^{n} \Delta L T D_{(t-j)}+\zeta_{j} \sum_{j=0}^{n} \Delta P R M_{(t-j)}+\zeta_{j} \sum_{j=0}^{n} \Delta E Q U_{(t-j)}+\Omega E C M_{(-1)} \\
\Delta L T D=\alpha_{O}+\alpha_{j} \sum_{j=0}^{n} \Delta S T D_{(t-j)}+\alpha_{j} \sum_{j=0}^{n} \Delta R O A_{(t-j)}+\alpha_{j} \sum_{j=0}^{n} \Delta P R M_{(t-j)}+\alpha_{j} \sum_{j=0}^{n} \Delta E Q U_{(t-j)}+K E C M_{(-1)} \\
\Delta E Q U_{i t}=\eta_{o}+\eta_{j} \sum_{j=0}^{n} S T D_{i(t-j)}+\eta_{j} \sum_{j=0}^{n} \Delta L T D_{(t-j)}+\eta_{j} \sum_{j=0}^{n} \Delta R O A_{i(t-j)}+\eta_{j} \sum_{j=0}^{n} \Delta P R M_{i(t-1)}+U E C M_{(-1)}
\end{gathered}
$$


Where $\Delta$ represents first difference operator, $j$ stands for lag length, $i$ stands for each firm, nth is the maximum lag length distribution and $E C M_{t-1}$ is the hth error correction term obtained from the residuals generated from hth cointegrating equations. Equations (9-13) could be written in compact form as;

$$
A^{*}(\mathrm{~L}) \Delta X_{t}=\rho-\alpha \beta^{*} X_{t-1}+\varepsilon_{t}
$$

To analyse dynamic relationship between capital structure and performance of quoted manufacturing companies in Nigeria, the study uses Panel Vector Error Correction Mechanism (PVECM) with a particular interest in forecast variance error decompositions. The choice of this method is informed by its ability to provide the effect magnitude in percentage $(\%)$ of the variations that occur to a particular variable as a results of innovations from another variable (s) in the system.

\section{Empirical Analysis}

\section{Panel Unit Root}

First, panel unit root test results are presented in Table 1. This is done with a view to determining stationarity properties and the order of integration of the variables. The study therefore employs Levin, Lin and Chu t*, ADF-Fisher Chi-square and PP-Fisher Chi-square panel unit root tests which have the null hypothesis of the presence of unit root (non-stationarity) in the data. From Table 1, at the constant effects, the results imply that the unit root hypothesis is not rejected for profit margin (PRM), returns on assets (ROA), equity (EQU), short term debts (STD) and long term debts (LTD) respectively. Based on ADF-Fisher Chi-square test, the null hypotheses of non-stationarity could not be rejected at levels in respect of all our variables of interest. They are first-differenced variables.

Table 1. Panel unit root tests

\begin{tabular}{llllll}
\hline \multirow{2}{*}{ Variables } & \multicolumn{2}{l}{ Levin, Lin and Chu t* } & \multicolumn{2}{l}{ ADF-Fisher Chi-Square } & \multicolumn{2}{c}{ PP-Fisher Chi-Square } \\
\cline { 2 - 6 } & Statistic & Prob. & Statistic & Prob. & Statistic \\
\hline PROF & 0.40766 & 0.9604 & 47.0546 & 0.9559 & 66.0194 \\
D (PROF) & -2.9076 & $0.0023^{* *}$ & 146.742 & $0.0014 *$ & 356.018 \\
ROA & -4.49717 & 0.0670 & 99.055 & 0.0692 & 310.993 \\
D (ROA) & -12.9645 & $0.0061^{* *}$ & 265.647 & $0.0001 * *$ & 85.524 \\
STD & -5.25939 & 0.0721 & 148.169 & 0.0652 & 184.745 \\
D (STD) & -10.0544 & $0.0003 *$ & 257.092 & $0.0000^{*}$ & 574.064 \\
LTD & -0.78678 & 0.3883 & 41.5288 & 0.9996 & $0.0000^{*}$ \\
D (LTD) & -2.86666 & $0.0069 * *$ & 192.579 & $0.0042^{* *}$ & 0.0934 \\
EQU & -3.21560 & 0.00721 & 121.7521 & $0.00421 * * *$ & 274.420 \\
D (EQU) & -4.38712 & 0.42171 & 217.4256 & $0.00301 * *$ & 197.2310 \\
\hline
\end{tabular}

The integrational properties of panel data based on the evidence of the panel unit root results, using constant effects in the estimation have shown that profit margin (PRM), returns on assets (ROA), equity (EQU), short term debts (STD) and long term debts (LTD) are integrated of order one, i.e. I (1) process. Also, using the constant and trend effects, individual linear trends in the estimation of the panel unit root as shown in Table 1, the order of integration reveals that the variables are integrated of order one I (1) with both ADFFisher Chi-square and PP-Fisher Chi-square tests results.

\section{Panel Cointegration}

Panel data offers advantages over time series when testing for cointegration on account of a larger number of observations which reduce the problem of lower power of cointegration test that could be commonly found in time series. Having known the order of integration of the variables, therefore, the Pedroni cointegration test is employed. Pedroni cointegration test is a very popular panel cointegration tests for allowing heterogeneity in the errors across cross-sectional units, while cointegration vector could vary across different sections of the panel. In this study, therefore, Pedroni Cointegration method is used to examine the existence of long run relationship among profit margin (PRM), returns on assets (ROA), equity (EQU), short term debts (STD) and long term debts (LTD). The results of Pedroni cointegration for five models are pasted in Tables 2 and 3. While Table 2 contains cointegration results for models 1 and 2, Table 3 contains the results for models 3, 4 and 5 respectively.

Table 2. Pedroni Panel Cointegration Tests Results for Models 1-2.

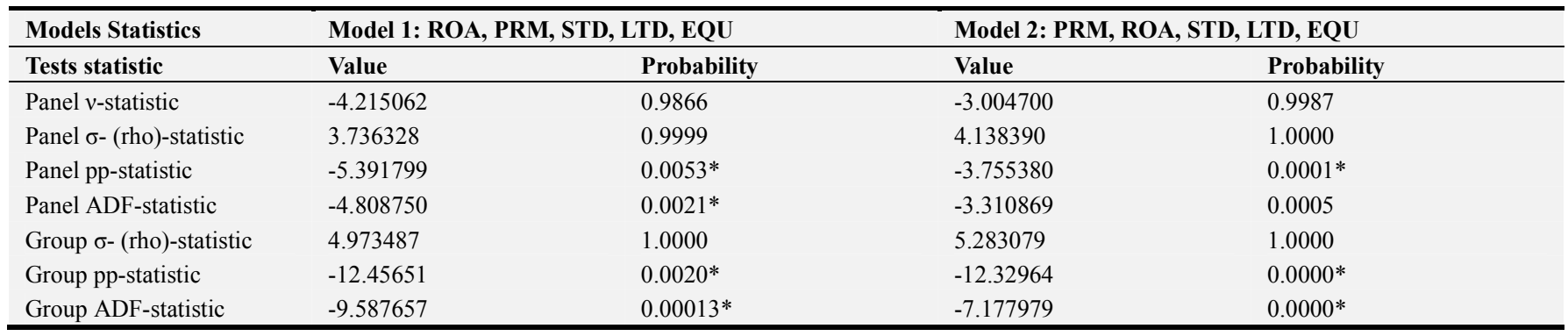


Table 3. Results of Pedroni Panel Cointegration Tests for Models 3-5.

\begin{tabular}{|c|c|c|c|c|c|c|}
\hline \multirow{2}{*}{$\begin{array}{l}\text { Models Statistics } \\
\text { Tests statistic }\end{array}$} & \multicolumn{2}{|c|}{ Model 3: PRM, ROA, STD, LTD, EQU } & \multicolumn{2}{|c|}{ Model 4: STD, PRM, ROA, LTD, EQU } & \multicolumn{2}{|c|}{ Model 5: LTD, PRM, STD, ROA. EQU } \\
\hline & Value & Probability & Value & Probability & Value & Probability \\
\hline Panel v-statistic & -2.12342 & 0.9833 & -2.694543 & 0.9965 & -2.971665 & 0.9985 \\
\hline Panel $\sigma$ - (rho)-st & 3.71434 & 0.9999 & 3.040965 & 1.0000 & 4.067277 & 1.0000 \\
\hline Panel pp-statistic & -4.93977 & $0.0026^{*}$ & -5.034943 & $0.0170 *$ & -5.276798 & $0.0136 * *$ \\
\hline Panel ADF-statist & -3.93225 & $0.0032 *$ & -4.405703 & $0.0003 *$ & -4.425132 & $0.0003 *$ \\
\hline Group $\sigma-($ rho)-st & 4.698197 & 1.0000 & 4.282024 & 1.0000 & -7.19068 & $0.0070^{*}$ \\
\hline Group pp-stat & -11.2300 & $0.0029 *$ & -14.57015 & $0.0015^{*}$ & -13.81508 & $0.0031 *$ \\
\hline
\end{tabular}

Pedroni panel cointegration tests results suggest that we could reject the null hypothesis of no cointegration in all the six models. Therefore, there is evidence of the existence of five cointegrating equations. It is, therefore, concluded that there is a long run equilibrium relationship among the variables, since the null hypothesis of no cointegration is rejected at $1 \%, 5 \%$ and $10 \%$ levels of significance for different models. On the number of optimal lag length to be included in the models as a prerequisite to the VAR/VECM techniques of estimation, in this case, Final Prediction error (FPE), Likelihood Ratio test statistic (LR), Schwarz information criterion (SIC), Akaike information criterion (AIC), and Hannan-Quinn information criterion (HQ) are examined and the optimal number is picked.

\section{Results and Discussion}

\subsection{Forecast Error Variance Decompositions of Returns on Asset (ROA)}

The results of forecast error variance decomposition of returns on asset (ROA) in Table 4 shows that (ROA) explains above $97 \%$, on average, forecast error variation of its own innovations for all the ten periods. In the first quarter, the variable explains total variation $(100 \%)$ of its own shocks, while there is little reduction in its total variations (96\%) at the end of the tenth period. From the results, it could be observed that, in the first period, none of the other variables' shocks in the system accounted for any variations in the returns on asset (ROA). This implies that at period one forecast error variance of returns on asset (ROA) solely depends on the innovations of its own in the system.

From the results, throughout the period, shocks from profit margin (PRM) contributes less than $1 \%$ to variations of returns on asset. One standard deviation from equity (EQU) explains the forecast error variation in ROA more than any other variable in the system. On average, one standard innovation to (EQU) explains $1 \%$ variation to returns on asset (ROA) of quoted manufacturing firms in Nigeria. The development suggests that profit margin (PRM) is an important and strong factor driving returns on asset in the manufacturing firms in Nigeria. The result is in agreement with the work of the study [16], where equity determined the returns on asset of the firms. However, innovations from short term debts (STD) and long term debts (LTD) contribute less than 1 percent of the forecast error variance of returns on asset throughout the 10 period time horizons.

Table 4. Results of Forecast Error Variance Decomposition of ROA.

\begin{tabular}{|c|c|c|c|c|c|c|}
\hline Period & S. E. & ROA & PRM & EQU & STD & LTD \\
\hline 1 & 4.620974 & 100.0000 & 0.000000 & 0.000000 & 0.000000 & 0.000000 \\
\hline 2 & 6.399463 & 99.57896 & 0.005177 & 0.347838 & 0.001167 & 0.000374 \\
\hline 3 & 7.679967 & 99.23143 & 0.008649 & 0.579953 & 0.006772 & 0.001256 \\
\hline 4 & 8.693351 & 98.91590 & 0.010850 & 0.716513 & 0.018850 & 0.002646 \\
\hline 5 & 9.533019 & 98.58238 & 0.012458 & 0.800173 & 0.038769 & 0.004536 \\
\hline 6 & 10.24848 & 98.20852 & 0.013832 & 0.854060 & 0.067635 & 0.006921 \\
\hline 7 & 10.86993 & 97.78626 & 0.015154 & 0.889964 & 0.106412 & 0.009792 \\
\hline 9 & 11.90531 & 96.79286 & 0.018007 & 0.930485 & 0.216980 & 0.016953 \\
\hline 10 & 12.34398 & 96.22588 & 0.019643 & 0.941021 & 0.290130 & 0.021223 \\
\hline
\end{tabular}

\subsection{Forecast Error Variance Decomposition of Profit Margin (PRM)}

Table 5. Results of Forecast Error Variance Decomposition of PRM.

\begin{tabular}{llllll}
\hline Period & S. E. & ROA & PRM & EQU & STD \\
\hline 1 & 0.732315 & 0.326990 & 99.45201 & 0.000000 & 0.000000 \\
2 & 0.050094 & 0.370826 & 97.95648 & 0.190658 & 0.006719 \\
3 & 0.295035 & 0.447854 & 96.64824 & 1.956420 & 0.015754 \\
4 & 0.500379 & 0.467976 & 95.62738 & 1.258757 & 0.026919 \\
5 & 0.680343 & 0.526907 & 94.72768 & 1.496186 & 0.0000070731 \\
6 & 0.842523 & 0.592676 & 93.96625 & 1.643950 & 0.006548 \\
7 & 1.491474 & 0.674247 & 93.20604 & 1.738997 & 0.057646 \\
8 & 2.030158 & 0.710986 & 92.43121 & 1.800635 & 0.078015 \\
\hline
\end{tabular}




\begin{tabular}{lllllll}
\hline Period & S. E. & ROA & PRM & EQU & STD & LTD \\
\hline 9 & 2.160617 & 0.802441 & 92.93592 & 1.839752 & 0.130121 & 0.080728 \\
10 & 2.384322 & 0.898252 & 91.61920 & 1.012930 & 0.162200 & 0.095959 \\
\hline
\end{tabular}

Results of variance error decomposition of profit margin (PRM) in table 5 shows that PRM explains $99.5 \%$ and $91.6 \%$ variations of its' owns variations in the first and tenth periods respectively. In the first period, it is only returns on asset (ROA) that records $0.33 \%$ of the forecast error variance on profit margin (PRM) at current period. This may explain the importance of returns on asset as driving force for profit margin of quoted manufacturing companies in Nigeria. Generally, throughout the period, innovations from equity (EQU) is more important in explaining forecast error variance of profit margin than any variable in both short run, given $1.2 \%$ in second period and $3.01 \%$ in the tenth period respectively. Innovations from short term debts and long term debts explains less than $1 \%$ forecast error variance of the profit margin with $0.02 \%, 0.04 \%$ and $0.16 \%$ in first, fifth and tenth quarters from (STD) and $0.00 \%, 0.02 \%$ and $0.1 \%$ from (LTD) respectively. This finding is consistent with [1] for Nigerian economy.

\section{Conclusion}

The study investigated the dynamic relationship between capital structure and firms' performance in Nigeria from 1990 to 2016. The methodology employed in this work involved panel unit root and cointegration tests. Also, panel vector autoregressive distributed lag was employed to analyse the data. The findings revealed that there were long run relationship among capital structure variables and measures of firms' performance in Nigeria during the period under review. The results also showed that, throughout the period, none of the other variables' shocks in the system accounted for any variations in the returns on asset (ROA), given variance error decomposition's statistics. Similarly, both in the short and long run, innovations from capital market structure were not statistically significant in explaining forecast error variance occurred to profit margin (PRM). The result implied that neither long term debts, short term debts, nor equity had strong relationship with PRM. Arising from these findings, the study could not find dynamic relationship between capital structure and firms' performance in economy of Nigeria.

\section{References}

[1] Olokoyo, F. O. (2013). Capital Structure and Corporate Performance of Nigerian Quoted Firms: A Panel Data Approach. African Development Review, 25 (3), 1-21.

[2] Akinsulire, O. (2014). Financial Management, 6th Edition, Ikeja, Ceemol Nig. Ltd.

[3] Kinde, R. A. (2013). Impact of Firm Level Factors on Capital
Structure: Evidence from Ethiopian Insurance Companies. Global Journal of management and Business Research 13 (4), $1-9$.

[4] Siddiqui, M. A. \& Shoab, A, (2011). Measuring Performance through Capital Structure: Evidence from Banking Sector of Pakistan. African Journal of Business Management 5 (5), 1871-1879.

[5] Tian, G. G. \& Zeitun, R. (2007). Capital Structure and Corporate Performance: Evidence from Jordan. Australian Accounting Business and Finance Journal, 1 (4): 40-61.

[6] De Angelo, H. \& Masuli, R. W. (1980). Optimal Capital Structure under Corporate and Personal Taxation. Journal of Financial Economics, 8: 3-29.

[7] Getzmann, A., Lang, S. \& Spremann, K. (2010). Determinants of the Target Capital Structure and Adjustment Speedevidence from Asian Capital Markets. European Journal of Financial Management, 1: 1-30.

[8] Mishra, C. S. (2011) Determinants of Capital Structure - A Study of Manufacturing Sector PSUs in India. International Conference on Financial Management and Economics, 11, 247-252.

[9] Ajeigbe, K. B., Fasesin, O. O. \& Ajeigbe, O. M. (2013). Nigeria Ailing Industries and the Capital Structure Theory: A need for Concern. Australian Journal of Business and Management Research, 3 (8): 31-40.

[10] Chechet I. L, Garba, S. L \& Odudu, A. S (2013). Determinants of capital Structure in the Nigerian Chemical and Paints Sector. International Journal of Humanities and Social Science, 3 (15), 247-263.

[11] Hasan, B., Ahsan, A. F. M. M., Rahaman, M. A., Alam, N. (2014). Influence of Capital Structure on Firm Performance: Evidence from Bangladesh. International Journal of Business and Management, 9 (5), 184-194.

[12] Javed, T. Younas, W. \& Imiran, M. (2014). Impact of Capital Structure on Firm Performance: Evidence from Pakistani Firms. International Journal of Academic Research in Economics and Management Sciences, 3 (5), 28-52.

[13] Hossain, A. T. \& Nguyen, D. X. (2016). Capital Structure, Firm Performance and the Recent Financial Crisis. Journal of Accounting and Finance, 16 (1), 76-89.

[14] Nenu, E. A., Vintila, G. \& Gherghina, S. V. (2018). The Impact of Capital Structure on Risk and Firm Performance: Empirical Evidence for the Bucharest Stock Exchange Listed Companies. International Journal of Financial Studies, 6 (41), $1-29$.

[15] Vatavu, S. (2015). The Impact of Capital Structure on Financial Performance in Romanian Listed Companies. Procedia Economics and Finance 32, 1314 - 1322.

[16] Huang, G. \& Song, F. M. (2006), The Determinants of Capital Structure: Evidence from China, China Economic Review, 17 (1), 14-36. 